\title{
Financial and Business Advisory Services for Small and Medium Enterprises and Entrepreneurs in Agribusiness in Serbia
}

\author{
Article history: \\ Received: 31 August 2017 \\ Sent for revision: 6 September 2017 \\ Received in revised form: 5 October 2017 \\ Accepted: 5 October 2017 \\ Available online: 25 December 2017
}

\begin{abstract}
Small and Medium-sized Enterprises and Entrepreneurs (SMEE), as a Sector, can take on a major role in agricultural development of the Republic of Serbia. However, in order to develop these enterprises, it is necessary to provide financial resources for their establishment and development, as well as appropriate business advisory support. This paper analyzes the issues regarding agribusiness companies financing, and interprets the use of advisory services. The aim of this analysis is to prove that small and medium-sized enterprises, entrepreneurs and farmers in particular, have limited access to financing and advisory services compared to larger companies. A survey that included 119 companies was conducted during this project. The obtained responses were stratified according to company size into three groups: entrepreneurs and farmers, small and medium-sized enterprises and large enterprises. The results showed that there were statistically significant differences between entrepreneurs and farmers, small, medium and large enterprises in most of the monitored parameters.
\end{abstract}

Keywords: SMEE, agribusiness, financing, loans, business advisory services

\footnotetext{
${ }^{1}$ School of Business, Novi Sad, boba jovin@yahoo.com

2 ODS EPS Distribucija, Novi Sad

${ }^{3}$ Mayor of Subotica

${ }^{4}$ School of Business, Novi Sad
} 
JovinS. et al.: Financial and Business Advisory Services for Small and Medium...

\title{
Finansijske i savetodavne usluge za mala i srednja preduzeća i preduzetnike u agrobiznisu u Srbiji
}

\begin{abstract}
Apstrakt: U Republici Srbiji sektor malih i srednjih preduzeća i preduzetnika, može imati veliku ulogu u u razvoju poljoprivrede. Međutim, da bi se ova preduzeća razvijala potrebno je obezbediti finansijske resurse za njihovo osnivanje i razvoj kao i odgovarajuću savetodavnu podršku. Rad se bavi analizom problema u finansiranju preduzeća iz oblasti agrobiznisa $i$ analizom korišćenja savetodavnih usluga. Cilj rada je da se dokaže da mala i srednja preduzeća a naročito preduzetnici i individualni poljoprivredni proizvođači imaju otežan pristup finansijskim sredstvima i savetodavnim uslugama u odnosu na velika preduzeća. U radu je izvršeno anketno istraživanje u kojem je učestvovalo 119 preduzeća. Dobijeni odgovori su grupisani u zavisnosti od veličine preduzeća u tri grupe: preduzetnici $i$ individualni poljoprivredni proizvođači, mala i srednja preduzeća i velika preduzeća. Dobijeni rezultati su pokazali da postoje statistički značajne razlike između preduzetnika $i$ individualnih poljoprivrednih proizvođača, malih, srednjih i velikih preduzeća u većini posmatranih parametara.
\end{abstract}

Ključne reči: MSPP, agrobiznis, finansiranje, krediti, savetodavne usluge

\section{Introduction}

Small and Medium-sized Enterprises and Entrepreneurs (SMEE) play an important role in the economic development of the Republic of Serbia. Small and Medium-sized Enterprises Sector constitutes $99.8 \%$ of the total number of companies, employs $65.1 \%$ workers, makes up a total of $65.4 \%$ of turnover and creates 34\% of GDP (Ministry of Economy of Republic of Serbia, Ministry of Regional Development and Local Government of Republic of Serbia, National Agency for Region Development of Republic of Serbia, 2013).

Due to above enlisted contributions to the economic development, and to acceleration of regional development, SMEE Sector should be the main pillar of the strategic objectives implementation (Popović, 2009; Support strategy for SMEE development and competitiveness for 2015 to 2020 period). One of these strategic goals is to promote and support the development of Agriculture.

Agribusiness is particularly important for small and medium-sized companies as it involves a wide economic domain. This includes production and processing of agriculture and food products, as well as input of agriculture production. The experience of the majority of world's developed economies confirms the fact that SMEE's can withstand the process of globalization, 
JovinS. et al.: Financial and Business Advisory Services for Small and Medium...

because of their ability to detect business opportunities more swiftly and win over new markets.

These enterprises have a diversity of business activities that allow them to use cheaper resources and to employ young people. That would contribute to improving the quality of life and development of all rural areas with the use of existing natural and human resources (Maletić et al., 2011).

Therefore, supporting the development of the SMEs sector, among other things, aims to facilitate access to funds for the establishment and development of these enterprises, particularly bearing in mind the specificity and sensitivity of agricultural production.

The paper analyzes difficulties in financing small and medium enterprises and entrepreneurs and farmers and the use of business advisory (non-financial) services in the field of agribusiness. Starting from the above stated, this paper will test the following hypotheses:

$\mathrm{H} 1$ : Small and medium-sized enterprises, and particularly entrepreneurs and farmers in the sector of agribusiness have the biggest difficulties in financing, and the high costs of financing are a major constraint;

$\mathrm{H} 2$ : While business advisory services can significantly improve the business of small and medium sized enterprises, entrepreneurs and farmers, they are still not used sufficiently and a certain number of small and medium-sized enterprises, entrepreneurs and farmers is unaware of their usage.

\section{Literature review}

By analyzing the literature on the agricultural financing, it can be noted that the main problem of research are determinants related to access to loan. However, few authors have analyzed the limitations in access to loan for small and medium enterprises in relation to large enterprises.

According to the Global Competitiveness Report 2016-2017, high tax rates in the Republic of Serbia represent the leading limitation in enterprises' activities, complex bureaucratic procedures are in the second place while access to finance is in the $4^{\text {th }}$ place. According to the same Report, considering the Affordability of Financial Services, Serbia is ranked as $124^{\text {th }}$ out of a total of 138 countries, according to Ease of access to loans, it is $73^{\text {rd }}$, while according to Venture capital availability Serbia is ranked as $104^{\text {th }}$ out of 138 countries (World Economic Forum, 2017). This is all in favor of the difficult access to funding sources, especially for the SME sector. Observed ranks of neighboring countries are found in the following table. 
JovinS. et al.: Financial and Business Advisory Services for Small and Medium...

Table 1. Global Competitiveness Index

\begin{tabular}{|l|r|r|r|r|}
\hline & \multicolumn{1}{|c|}{$\begin{array}{c}\text { Global } \\
\text { rank/138 }\end{array}$} & $\begin{array}{c}\text { Affordability of } \\
\text { financial services }\end{array}$ & $\begin{array}{c}\text { Ease of access to } \\
\text { loans }\end{array}$ & $\begin{array}{c}\text { Venture capital } \\
\text { availability }\end{array}$ \\
\hline Serbia & 90 & 124 & 73 & 104 \\
\hline Albania & 80 & 92 & 106 & 124 \\
\hline Macedonia & 68 & 60 & 45 & 50 \\
\hline Montenegro & 82 & 104 & 97 & 67 \\
\hline $\begin{array}{l}\text { Bosnia and } \\
\text { Herzegovina }\end{array}$ & 107 & 115 & 68 & 101 \\
\hline Croatia & 74 & 112 & 95 & 106 \\
\hline Hungary & 69 & 63 & 29 & 60 \\
\hline Romania & 62 & 121 & 110 & 125 \\
\hline Bulgaria & 50 & 67 & 41 & 47 \\
\hline
\end{tabular}

Source: Global Competitiveness Report, 2017

Based on the Table 1, observing the neighboring countries (Albania, Macedonia, Montenegro, Bosnia and Herzegovina, Croatia, Hungary, Romania and Bulgaria), only Bosnia and Herzegovina has a lower global competitiveness rank (107) than Serbia. When it comes to Affordability of financial services, Serbia ranked as $124^{\text {th }}$ is ranked lower than observed neighboring countries. Looking at Ease of access to loans, Serbia ranked as $73^{\text {rd }}$ is in a better position than Albania, Montenegro, Croatia and Romania. When it comes to Venture capital availability, Serbia is in a better position than Albania, Croatia and Romania (Global Competitiveness Report, 2017).

According to the Doing Business Report (World Bank, 2017), Serbia is ranked as $47^{\text {th }}$ out of 190 countries. Compared to neighboring countries (Albania, Macedonia, Montenegro, Bosnia and Herzegovina, Croatia, Hungary, Romania and Bulgaria), Serbia is better positioned than Albania, Montenegro and Macedonia.

Although Serbia shows an improvement in rankings in the previous period, previous data indicate a worse position of Serbia in relation to neighboring countries, as well as difficulties in financing, and difficulty for funding by a venture capital fund (more details in Filipović, Petrović, 2017). When it comes to small and medium enterprises and entrepreneurs in the field of agribusiness, these problems are especially evident.

In addition to the structural constraints which impose the majority of problems that enterprises and entrepreneurs face, another limitation is the poor access to finances because small and medium enterprises are limited to selffinancing in cash, and they are not familiar with the available sources of funding and they do not know how and where to apply for a loan (Ljumović, \& Jakšić, 2015).

Many authors believe that the lack of financial resources is one of the major constraints in the development of the SMEs sector. 
JovinS. et al.: Financial and Business Advisory Services for Small and Medium...

The big problem is access to financial sources and underdeveloped offer of financial products and services for SMEs, which caused a downward trend in approved loans to this sector (Filipović, \& Petrović, 2017).

Malthora et al. (2006) claim that the major constraint that small enterprises face is difficult access to financial funds, and that it is a much bigger barrier for small enterprises than for large ones.

Looking at the agribusiness sector, the lack of financial resources is a major limiting factor in the efficient use of agricultural resources in both countries in transition and developed countries (Ciaian et al., 2010).

In the Republic of Serbia, access to funds is weakest for farmers and small and medium enterprises within agricultural sector in comparison to other industries. The financial sector in Serbia offers a small number of credit services in the agricultural sector (Veselinović, \& Drobnjaković, 2014).

Most problems in obtaining funds are present within SMEs sector. Most small enterprises and entrepreneurs begin their business using their own resources or savings, with the help of their families or partners (Casu et al., 2006). When this source is not enough, they turn to banks.

Most farms have demands for short-term loans because farmers have a certain period of time between paying for the fertilizer and the income from selling their products. That is why their demand for loan can be satisfied either internally, by using cash or savings, or externally by taking a bank loan (Ciaian et al., 2011).

The state and the subsidized loans, commercial banks, leasing companies and development funds are main sources of funding of the agricultural sector in the Republic of Serbia. The international financial institutions approve the appropriate lines of credit to domestic banks as intermediaries, with the intention to finance the improvement of agriculture in our country. However, these sources are not sufficient to meet the financial needs of the agricultural sector and banks are often not the most appropriate source of funding, because they avoid risk, and financing newly established, small and medium enterprises is risky.

The growth of Non-performing Loans (NPL) in the post-crisis period in the Republic of Serbia negatively affects the lending activity of banks, thereby reducing the ability of enterprises, especially entrepreneurs to finance their business and then to service due liabilities. This leads to more stringent conditions for the approval of new loans, and the prospects for intensive growth in banks' profitability are modest (Miljković, Filipović, \& Tanasković, 2013). However, external resources are necessary for most enterprises (Bygrave, \& Zacharakis, 2004; Casu et al., 2006).

Due to low creditworthiness and unreliable data on the financial situation of enterprises and entrepreneurial ventures, access to external sources of 
JovinS. et al.: Financial and Business Advisory Services for Small and Medium...

financing is difficult. Credit conditions are unfavorable, and the application procedure is time-consuming. Banks grant loans to enterprises with a positive cash flow, good financial performance, high-quality financial statements and high-quality collateral, which is a problem particularly for small enterprises, entrepreneurs and farmers.

Some studies show that the lack of high-quality collateral is the biggest obstacle in obtaining loans followed by the lack of credit history (Stokes, \& Wilson, 2010).

Loans secured by real estate have much lower interest rates. The reduction of interest rates in the case of real estate collateral is very important, because it reflects the perceptions of bankers that real estate collateral is a reasonable insurance regarding losses and risks (Walraven, \& Barry, 2004).

However, most banks will not approve a loan if an enterprise does not has positive cash flows regardless of the collateral offered (Van Horne, \& Wachowicz, JR, 2007; Höflich, 2011). On the other hand, preparing cash flow statements is difficult for small enterprises and entrepreneurs. Negative cash flows are one of the main reasons for banks to refuse loans (Scarborough, 2012).

When it comes to newly established enterprises, problems are even more complex because they do not have the financial statements for the previous period, so enterprises do not have a history of business and they have no collateral.

Each activity is risky, but agriculture is specific in terms of risk. High risk means high interest rates as the cost of risk. This is confirmed by research (Ayyagari et al., 2008) where it was concluded that high interest rates affect the requirement for high levels of required collateral and the number of requested documents.

According to the National Agency for Regional Development in 2013, $78 \%$ of enterprises consider that high interest rates are the biggest obstacle in their activity. According to the National Survey of Business conducted by the USAID (2012), over $60 \%$ of surveyed enterprises consider it hard to get a loan, pointing out that their access to funds has not improved. It is much worse result than in middle-income countries where $30 \%$ of small and medium enterprises and only $15 \%$ of SMEs in highly developed countries answered in such a way. Also, enterprises feel that services are not adjusted to their needs, so as much as $60 \%$ of the SMEs sector considers that the loan repayment period, repayment terms and collateral do not suit their current needs.

Successful development of an enterprise, in addition to financial resources requires non-financial and business advisory support as well. 
JovinS. et al.: Financial and Business Advisory Services for Small and Medium...

Some authors point to the importance of entrepreneurship training and practicing because of the modest entrepreneurial abilities of entrepreneurs (Cvijanović, Rodica, Vojnović, \& Živković, 2013).

Cassar and Holmes (2003) emphasized the importance of business advisory services. The differences between small and large enterprises in making financial and other decisions are the result of weaker skills and knowledge of small enterprise owners and entrepreneurs, who usually do not have access to appropriate professional business advice.

According to the Law on Performing Advisory and Extension Activities in Agriculture (Official Gazette of RS, no. 30/2010) business advisory services in agriculture are carried out in order to raise the general level of knowledge of farmers, increase the competitiveness and modernization of agricultural production, increase the profitability of production and product quality, environmental protection and rural development.

Type of professional advice depends on the proficiency of management, activities of an enterprise and other factors. Independent business advisory will increase the effectiveness of implementation of entrepreneurial ventures (Reuvid, 2011).

In the Republic of Serbia, the existing infrastructure and systems of knowledge transfer are not effective enough and they fail to meet the needs of dynamic development of the agricultural sector.

\section{Data sources and Methodology}

An empirical study was conducted by collecting and analyzing primary data through a market survey in which 119 subjects were interviewed. Subjects were divided into three groups. The first group consisted of entrepreneurs and farmers, the second group consisted of small and medium-sized enterprises and the third group consisted of large companies. The criteria for the classification of the companies by size was acquired and based on the Accounting Act of Republic of Serbia 2013. The following table shows the structure of the sample according to the size of an enterprise.

Table 2. Description of the sample according to the size of an enterprise

\begin{tabular}{|c|l|c|c|}
\hline Variable & Category & $f$ & $\%$ \\
\hline \multirow{3}{*}{ Size of an enterprise } & Entrepreneurs and farmers & 45 & 37.82 \\
\cline { 2 - 4 } & Small and medium enterprise & 38 & 31.93 \\
\cline { 2 - 4 } & Large enterprise & 36 & 30.25 \\
\cline { 2 - 4 } & Total & 119 & 100 \\
\hline
\end{tabular}

Source: Authors' research 
JovinS. et al.: Financial and Business Advisory Services for Small and Medium...

Based on the presented data in the Table 2, it can be noted that the research sample consists of 119 enterprises, out of which 45 are entrepreneurs or farmers (37.82\%), 38 small and medium-sized enterprises (31.93\%) and 36 large enterprises (30.25\%).

The sample consists of enterprises engaged in agriculture and food production. The surveyed sample mostly consists of enterprises engaged in food production $(33.61 \%)$, followed by enterprises engaged in animal farming $(20.17 \%)$, plant cultivation (18.49\%) and service activities within the agriculture sector (15.97\%).

Sample analysis can also be composed according to the time period of engaging activities. Hence, there are $28.6 \%$ of enterprises that are in business less than 5 years, 26\% of those are active between 6 and 10 years, and there are $45.4 \%$ of enterprises with the longest tradition of operation of more than 10 years.

Based on their position in an enterprise, the sample consists of the following examinees: managers $(21.9 \%)$, farmers $(21.9 \%)$, heads of finance $21 \%$, entrepreneurs/founders $13.5 \%$, production managers 9.3\%, accounting managers $7.6 \%$, while other positions are present in smaller percentage $(4.8 \%)$.

According to the gender structure, $74 \%$ of men and $26 \%$ of women participated in the research. According to the education level, $75 \%$ of examinees have a college or a university degree, $24 \%$ of examinees have a secondary education degree and $1 \%$ of examinees have a primary education degree. The lower education level is mostly related to farmers.

Data was collected from October to December 2015, in the Republic of Serbia. The data was analyzed through the statistical program "SPSS Statistics 20.0". Analysis was based on the use of descriptive statistics, analysis of variance and the chi square test. After the descriptive analysis, a statistically significant difference $(p<0.05)$ was determined between the mean values for all three groups of enterprises. For the calculation of variance the following parameters were used: ss (sum of squares) or the sum of squared deviations, df (degrees of freedom) or the number of degrees of freedom, MS (mean square) or the average of the squared deviations, $\mathrm{F}$ test for analysis of variance and $p$ that represents the level of statistical significance for the value F.

Considering that there are three groups of enterprises, in order to determine between which mean values statistically significant difference is present, a post hoc test, or the subsequent test was used.

Examinees answered three groups of questions. The first group of questions referred to basic information about the person who filled out the survey 
JovinS. et al.: Financial and Business Advisory Services for Small and Medium...

(gender, position in the enterprise and qualification), information about the enterprise related to the classification by size, the core business of an enterprise and the time period of activities engagement.

In the second part of the survey examinees would rate their cooperation with banks which could constrain their financing. This part of the survey is designed as a Likert scale with five points, so that examinees could rate them from 1 to 5 (1 - very poor, 2 - poor, 3 - medium, 4 - good, 5 - very good). The following items were rated:

- The ability to offer a high-quality loan collateral to the bank;

- The level of interest rates and fees for loans and other services;

- The possibility of submitting the required information to banks for credit rating;

- The ease of access to loans;

- The support services development outside an enterprise (legal, business, institutional support);

- The quality of communication with banks

The aim of this part of the research is to assess whether there are differences present in responses of three observed groups (entrepreneurs and farmers, small and medium, and large enterprises) and whether given differences are statistically significant.

The last part of the survey was designed to determine whether the enterprises used business advisory services. If so, were they used within the national business advisory services or within private consulting centers? In the case of an affirmative response, the purpose of using business advisory services was further examined. This part of the research as well, aimed to prove that these three groups of examinees were not equally informed about the possibilities of business support services, and that there were statistically significant differences in the level and the type of used services.

\section{Results and Discussion}

\subsection{The financing issues of SMEE Sector in Agribusiness}

This part of the research aims to investigate the differences regarding difficulties of accessing finances in the field of Agribusiness, that entrepreneurs and farmers, small and medium and large enterprises encounter. Table 3 shows the results of the descriptive statistics for the whole sample. 
JovinS. et al.: Financial and Business Advisory Services for Small and Medium...

Table 3. Descriptive analysis of responses for the whole sample

\begin{tabular}{|c|c|c|c|c|c|c|c|}
\hline \multicolumn{8}{|c|}{ The whole sample } \\
\hline & $\mathrm{N}$ & Min & Max & $\mathrm{M}$ & SD & Skewness & Kurtosis \\
\hline $\begin{array}{l}\text { The ability to offer a } \\
\text { high-quality loan } \\
\text { collateral to the bank }\end{array}$ & 119 & 1 & 5 & 3.28 & .85 & 01 & -.36 \\
\hline $\begin{array}{l}\text { The level of interest } \\
\text { rates and fees for loans } \\
\text { and other services }\end{array}$ & 119 & 1 & 4 & 2.38 & .78 & -.13 & -.50 \\
\hline $\begin{array}{l}\text { The possibility of } \\
\text { submitting the required } \\
\text { information to banks for } \\
\text { credit rating }\end{array}$ & 119 & 2 & 5 & 3.47 & .95 & .10 & -.90 \\
\hline $\begin{array}{l}\text { The ease of access to } \\
\text { loans }\end{array}$ & 119 & 1 & 5 & 2.85 & .71 & .23 & -.13 \\
\hline $\begin{array}{l}\text { The support services } \\
\text { development outside an } \\
\text { enterprise } \\
\text { (legal, } \\
\text { business, institutional } \\
\text { support) }\end{array}$ & 119 & 2 & 5 & 3.45 & .90 & .18 & -.71 \\
\hline $\begin{array}{l}\begin{array}{l}\text { The quality of } \\
\text { communication with } \\
\text { banks }\end{array} \\
\end{array}$ & 119 & 2 & 5 & 3.39 & $\begin{array}{c}1.0 \\
4\end{array}$ & .22 & -1.11 \\
\hline
\end{tabular}

Source: Authors' research

Based on the Table 3, it can be noticed that indicators of distribution curvature and flatness show that the responses to the items are normally distributed (Skewness and Kurtosis within the interval $-1,+1$ ). This is important for the parametric statistical analysis showed in the following text.

Table 4 shows the descriptive statistics for the observed groups of enterprises. Columns refer to the number of examinees in the observed group, the minimum and maximum rating obtained within the testing, the average rating and standard deviation.

Based on the Table 4, results of the descriptive analysis showed that the ability of offering high-quality loan collateral to the bank is a major problem for entrepreneurs and farmers who rated this item with a low average of 2.73. SMEs have difficulties when banks requiring collateral in the form of a mortgage loan, so they rated this item with an average of 3.13 . The public warehouse and the pledge system are undeveloped, thus hindering farmer's access to capital. Large enterprises are not spared of this problem either, but they, nevertheless, are in better position since they often own a registered property they can offer to the bank as a collateral. This is confirmed by a relatively high rating of this item with 4.11 by large enterprises. Considering that, it can be concluded that the inability of obtaining high-quality collateral may pose a difficulty for SME sector, entrepreneurs and farmers when accessing the funding resources. 
JovinS. et al.: Financial and Business Advisory Services for Small and Medium...

Table 4. Descriptive analysis of the responses according to the size of an enterprise

\begin{tabular}{|c|c|c|c|c|c|}
\hline \multicolumn{6}{|c|}{ Entrepreneurs and farmers } \\
\hline & $\mathrm{N}$ & Min & $\operatorname{Max}$ & $\mathrm{M}$ & SD \\
\hline $\begin{array}{l}\text { 1. The ability to offer a high-quality loan } \\
\text { collateral to the bank }\end{array}$ & 45 & 1 & 4 & 2.73 & 69 \\
\hline $\begin{array}{l}\text { 2. The level of interest rates and fees for loans } \\
\text { and other services }\end{array}$ & 45 & 1 & 4 & 1.87 & .81 \\
\hline $\begin{array}{l}\text { 3. The possibility of submitting the required } \\
\text { information to banks for credit rating }\end{array}$ & 45 & 2 & 5 & 2.77 & .71 \\
\hline 4. The ease of access to loans & 45 & 2 & 5 & 2.38 & 68 \\
\hline $\begin{array}{l}\text { 5. The support services development outside } \\
\text { an enterprise (legal, business, institutional } \\
\text { support) }\end{array}$ & 45 & 2 & 4 & 2.78 & .64 \\
\hline 6. The quality of communication with banks & 45 & 2 & 5 & 2.67 & .74 \\
\hline \multicolumn{6}{|c|}{ Small and medium enterprises } \\
\hline & $\mathrm{N}$ & Min & Max & $\mathrm{M}$ & SD \\
\hline $\begin{array}{l}\text { 1. The ability to offer a high-quality loan } \\
\text { collateral to the bank }\end{array}$ & 38 & 2 & 4 & 3.13 & .62 \\
\hline $\begin{array}{l}\text { 2. The level of interest rates and fees for loans } \\
\text { and other services }\end{array}$ & 38 & 2 & 4 & 2.55 & .55 \\
\hline $\begin{array}{l}\text { 3. The possibility of submitting the required } \\
\text { information to banks for credit rating }\end{array}$ & 38 & 2 & 4 & 3.30 & .62 \\
\hline 4. The ease of access to loans & 38 & 1 & 4 & 2.95 & .46 \\
\hline $\begin{array}{l}\text { 5. The support services development outside } \\
\text { an enterprise (legal, business, institutional } \\
\text { support) }\end{array}$ & 38 & 2 & 5 & 3.42 & .64 \\
\hline 6. The quality of communication with banks & 38 & 2 & 5 & 3.13 & .70 \\
\hline \multicolumn{6}{|c|}{ Large enterprises } \\
\hline & $\mathrm{N}$ & Min & $\operatorname{Max}$ & $\mathrm{M}$ & SD \\
\hline $\begin{array}{l}\text { 1. The ability to offer a high-quality loan } \\
\text { collateral to the bank }\end{array}$ & 36 & 3 & 5 & 4.11 & .57 \\
\hline $\begin{array}{l}\text { 2. The level of interest rates and fees for loans } \\
\text { and other services }\end{array}$ & 36 & 2 & 4 & 2.83 & .56 \\
\hline $\begin{array}{l}\text { 3. The possibility of submitting the required } \\
\text { information to banks for credit rating }\end{array}$ & 36 & 4 & 5 & 4.51 & .51 \\
\hline 4. The ease of access to loans & 36 & 2 & 4 & 3.33 & .59 \\
\hline $\begin{array}{l}\text { 5. The support services development outside } \\
\text { an enterprise (legal, business, institutional } \\
\text { support) }\end{array}$ & 36 & 3 & 5 & 4.33 & .63 \\
\hline 6. The quality of communication with banks & 36 & 3 & 5 & 4.56 & .56 \\
\hline
\end{tabular}

Source: Authors' research

High interest rates and loan fees are a constraint in conducting business for all groups of examinees, since this item was rated as the lowest one by all of them. Entrepreneurs and farmers rated it with 1.87, small and medium-sized 
JovinS. et al.: Financial and Business Advisory Services for Small and Medium...

enterprises with 2.55 and large enterprises with 2.83. In this case as well, SMEE sector rated this item as the lowest one, especially entrepreneurs and farmers since they are highly dependent on banks, and due to size sensitivity to changing interest rates. On the other hand, large companies have access to other funding resources and a better bargaining power, so the interest rates are not such a limiting factor as for the SMEE sector.

While assessing credit ability of enterprises, banks require extensive documentation which usually includes financial statements for the previous period, financial business projections for the loan repayment period, cash flow projections, business plan, status documentation, etc. When it comes to the SMEE sector and farmers in particular, this can be quite difficult. So, this item was also rated as the worst one by entrepreneurs and farmers with 2.77, slightly better than the small and medium enterprises that rated it with 3.30 . However, documentation required by banks is not a big issue for large enterprises, so their average rating was significantly higher - with 4.51. Entrepreneurs and especially farmers generally do not have adequate financial and accounting knowledge. They often do not have the complete financial statements and information on the operation of an enterprise for the previous period, and frequently those are start-up enterprises.

Fast loan access is one of key items in agriculture, due to the seasonal nature of activities, and it is important to obtain an approved loan on time. For this reason, all groups of examinees found the speed of a loan approval as a major constraint immediately after the question of interest rate level. Also, this issue presents a higher limitation for entrepreneurs and farmers than for small, medium and large enterprises. Large enterprises, because of their size and professional staff, more easily meet banks' requirements, so they rated this item as very high. Although the quality of service is very important, fast and easy loan approval also, less complicated and shorter procedure is something that would mean a lot to the SMEE sector.

Development of external business support services, regarding the legal, business and institutional support is another item that the SMEE sector and farmers rated lower than large companies. Entrepreneurs and farmers gave it the lowest mark, while SME rated it lower than the large enterprises did. The lack of these services is not an issue for large enterprises, because they employ professional staff and are well informed about business support services outside an enterprise.

Communication quality with banks was also rated lower by the SMEE sector. Results of the descriptive analysis show that entrepreneurs and farmers rated quality of communication with banks with low average score of 2.67, SME with 3.13. In this case as well large enterprises were the most satisfied with the quality of communication with banks and rated it with 4.56 . Thus, the quality of communication became the item rated as the highest one of all observed 
JovinS. et al.: Financial and Business Advisory Services for Small and Medium...

items. Large enterprises are satisfied with the quality of communication because they longer cooperate with banks and have a better knowledge of their requirements.

Descriptive analysis was followed by the analysis of variance in order to determine whether there are statistically significant differences $(p<0.05)$ between the mean values for all observed groups. The calculated values are shown in the Table 5.

Table 5. Analysis of variance - differences between the responses in relation to the size of an enterprise

\begin{tabular}{|l|c|c|c|c|c|}
\hline \multicolumn{1}{|c|}{ Variable } & SS & df & MS & F & $\mathrm{p}$ \\
\hline $\begin{array}{l}\text { The ability to offer a high-quality loan } \\
\text { collateral to the bank }\end{array}$ & 39.15 & 2 & 19.58 & 48.63 & .000 \\
\hline $\begin{array}{l}\text { The level of interest rates and fees for } \\
\text { loans and other services }\end{array}$ & 20.39 & 2 & 10.19 & 22.92 & .000 \\
\hline $\begin{array}{l}\text { The possibility of submitting the } \\
\text { required information to banks for credit } \\
\text { rating }\end{array}$ & 60.66 & 2 & 30.33 & 77.54 & .000 \\
\hline $\begin{array}{l}\text { The ease of access to loans } \\
\text { The support services development } \\
\text { outside an enterprise (legal, business, } \\
\text { institutional support) }\end{array}$ & 48.45 & 2 & 24.23 & 59.74 & .000 \\
\hline $\begin{array}{l}\text { The quality of communication with } \\
\text { banks }\end{array}$ & 74.99 & 2 & 37.49 & 81.71 & .000 \\
\hline
\end{tabular}

Source: Authors' research

Based on the Table 5, analysis of variance showed that the responses of all groups of enterprises differ significantly because the resulting $p$ value is less than 0.05 in all responses. In order to determine between which groups of enterprises statistically significant differences are present, analysis of variance by Scheffe post hoc test was done.

According to the results presented in Table 6, results of the post hoc test showed that statistically significant difference is not present only in the second question related to the level of interest rates and fees, between the group of small and medium and large enterprises, due to the high interest rates constraints in both groups of enterprises. In all other cases, statistically significant difference is present among all groups of enterprises since the $p$ value is less than 0.05 .

It can be concluded that the given results confirm the first hypothesis $\mathrm{H} 1$ : Small and medium-sized enterprises, and particularly entrepreneurs and farmers in the sector of agribusiness have the biggest difficulties in financing, and the high costs of financing are a major constraint. 
JovinS. et al.: Financial and Business Advisory Services for Small and Medium...

Table 6. Scheffe post-hoc test for significant differences in the responses

\begin{tabular}{|c|c|c|c|c|c|}
\hline Variable & $\begin{array}{l}\text { Enterprise } \\
\text { size }\end{array}$ & $\begin{array}{l}\text { Enterprise } \\
\text { size }\end{array}$ & $\begin{array}{l}\text { Differences } \\
\text { in Mean }\end{array}$ & $\begin{array}{l}\text { Standard } \\
\text { deviation }\end{array}$ & $\mathrm{p}$ \\
\hline \multirow{3}{*}{$\begin{array}{l}\text { The ability to offer high- } \\
\text { quality collateral to the bank }\end{array}$} & $\begin{array}{l}\text { entrepreneurs } \\
\text { and farmers }\end{array}$ & $\begin{array}{l}\text { small and } \\
\text { medium }\end{array}$ & -.398 & .140 & .020 \\
\hline & $\begin{array}{l}\text { entrepreneurs } \\
\text { and farmers }\end{array}$ & large & -1.378 & .142 & .000 \\
\hline & $\begin{array}{l}\text { small and } \\
\text { medium }\end{array}$ & large & -.979 & .148 & .000 \\
\hline \multirow{3}{*}{$\begin{array}{l}\text { The level of interest rates } \\
\text { and fees for loans and other } \\
\text { services }\end{array}$} & $\begin{array}{l}\text { entrepreneurs } \\
\text { and farmers }\end{array}$ & $\begin{array}{l}\text { small and } \\
\text { medium }\end{array}$ & -.686 & . 147. & .000 \\
\hline & $\begin{array}{l}\text { entrepreneurs } \\
\text { and farmers }\end{array}$ & large & -.967 & 149 & .000 \\
\hline & $\begin{array}{l}\text { small and } \\
\text { medium }\end{array}$ & large & -.281 & .155 & .199 \\
\hline \multirow{3}{*}{$\begin{array}{l}\text { The possibility of submitting } \\
\text { the required information to } \\
\text { banks for credit rating }\end{array}$} & $\begin{array}{l}\text { entrepreneurs } \\
\text { and farmers }\end{array}$ & $\begin{array}{l}\text { small and } \\
\text { medium }\end{array}$ & -.525 & .140 & .001 \\
\hline & $\begin{array}{l}\text { entrepreneurs } \\
\text { and farmers }\end{array}$ & large & -1.742 & .142 & .000 \\
\hline & $\begin{array}{l}\text { small and } \\
\text { medium }\end{array}$ & large & -1.217 & .147 & .000 \\
\hline \multirow{3}{*}{ The ease of access to loans } & $\begin{array}{l}\text { entrepreneurs } \\
\text { and farmers }\end{array}$ & $\begin{array}{l}\text { small and } \\
\text { medium }\end{array}$ & -.569 & .130 & .000 \\
\hline & $\begin{array}{l}\text { entrepreneurs } \\
\text { and farmers }\end{array}$ & large & -.956 & .132 & .000 \\
\hline & $\begin{array}{l}\text { small and } \\
\text { medium }\end{array}$ & large & -.386 & .137 & .022 \\
\hline \multirow{3}{*}{$\begin{array}{l}\text { The development of support } \\
\text { services outside an } \\
\text { enterprise (legal, business, } \\
\text { institutional support) }\end{array}$} & $\begin{array}{l}\text { entrepreneurs } \\
\text { and farmers }\end{array}$ & $\begin{array}{l}\text { small and } \\
\text { medium }\end{array}$ & -.643 & 140 & .000 \\
\hline & $\begin{array}{l}\text { entrepreneurs } \\
\text { and farmers }\end{array}$ & large & -1.556 & .142 & .000 \\
\hline & $\begin{array}{l}\text { small and } \\
\text { medium }\end{array}$ & large & -.912 & .148 & .000 \\
\hline \multirow{3}{*}{$\begin{array}{l}\text { The quality of } \\
\text { communication with banks }\end{array}$} & $\begin{array}{l}\text { entrepreneurs } \\
\text { and farmers }\end{array}$ & $\begin{array}{l}\text { small and } \\
\text { medium }\end{array}$ & -.465 & .149 & .009 \\
\hline & $\begin{array}{l}\text { entrepreneurs } \\
\text { and farmers }\end{array}$ & large & -1.889 & .151 & .000 \\
\hline & $\begin{array}{l}\text { small and } \\
\text { medium }\end{array}$ & large & -1.424 & .158 & .000 \\
\hline
\end{tabular}

Source: Authors' research

\subsection{Advisory services in Agriculture}

Appropriate professional and educational support is one of the preconditions for development of enterprises in Agribusiness. In the Republic of Serbia, next to professional advisory services operating under the control of the government (35 agricultural professional advisory services are currently operating), number of private consultants is increasing. They are particularly preferential when it comes to business consulting services related to accessing finances, business plan, marketing assistance etc., while 
JovinS. et al.: Financial and Business Advisory Services for Small and Medium...

professional services for the agricultural production improvement are mainly provided by national institutions.

The aim of this part of the survey research is to determine whether enterprises use business advisory services and to what extent; who are the most frequent providers of these services; and to detect differences in the responses of the three groups of enterprises. Furthermore, the aim was to investigate how well informed are the enterprises about the possibility of using business advisory services. Figure 1 shows the results of the business advisory services usage as a part of national advisory services, related to the size of an enterprise.

Figure 1. Overview of the use of business advisory services as a part of national advisory services, according to the size of an enterprise

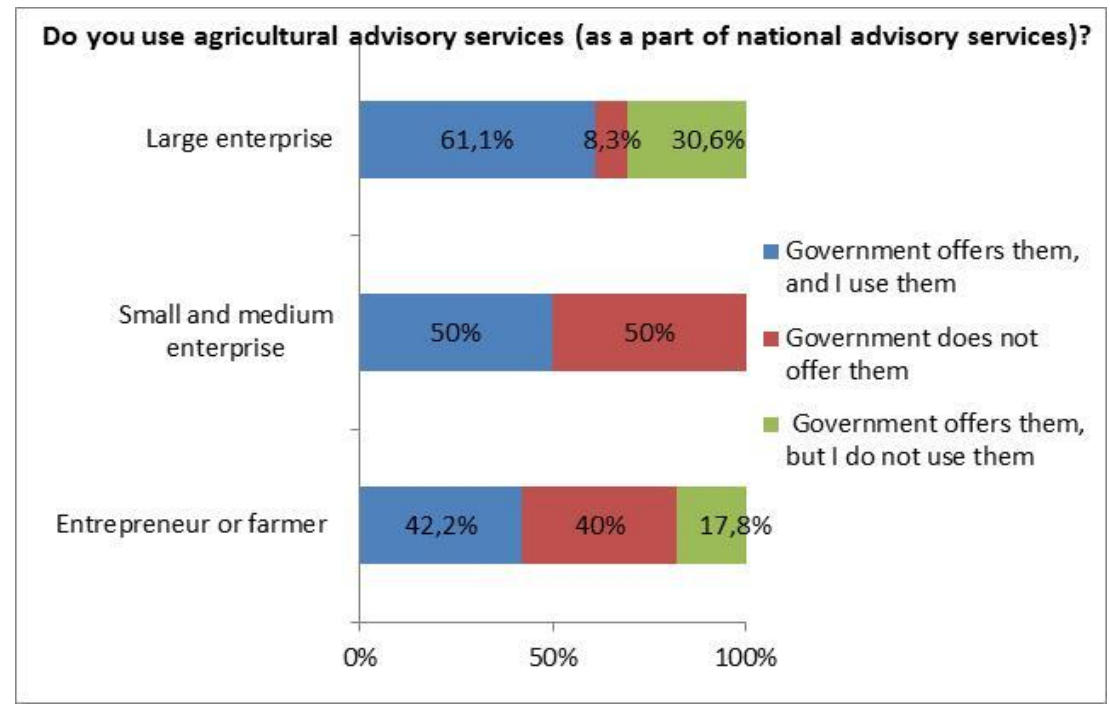

Source: Authors' research

Based on the research results presented in Figure 1, it can be concluded that for entrepreneurs and farmers, but for small and medium-sized enterprises as well, there is a lack of information about the possibility of using business advisory services within the national advisory services. As many as $40 \%$ of entrepreneurs and farmers and $50 \%$ of SMEs feel that the government does not offer these services, but only $8.3 \%$ of large enterprises agrees with it. However, enterprises that are familiar with the offering of these services use them to a great extent. Large enterprises mostly use these services $(61.1 \%)$, while only $50 \%$ of SMEs and $42.2 \%$ of entrepreneurs and farmers are using them. 
JovinS. et al.: Financial and Business Advisory Services for Small and Medium...

Furthermore, research showed that enterprises which declared positively to the previous question and which use business services within the national advisory services, mainly use services related to the improvement of agricultural production $(71.4 \%$ of entrepreneurs and farmers, $85.7 \%$ of small and medium-sized enterprises and $85 \%$ of large enterprises). Services related to accessing finances, development of business plans, etc., are less used within the national advisory services. In addition to national agricultural professional advisory services, enterprises can use one of many private consulting centers that provide a range of services.

Figure 2. Overview of the use of agricultural advisory services in private consulting centers, according to the size of an enterprise

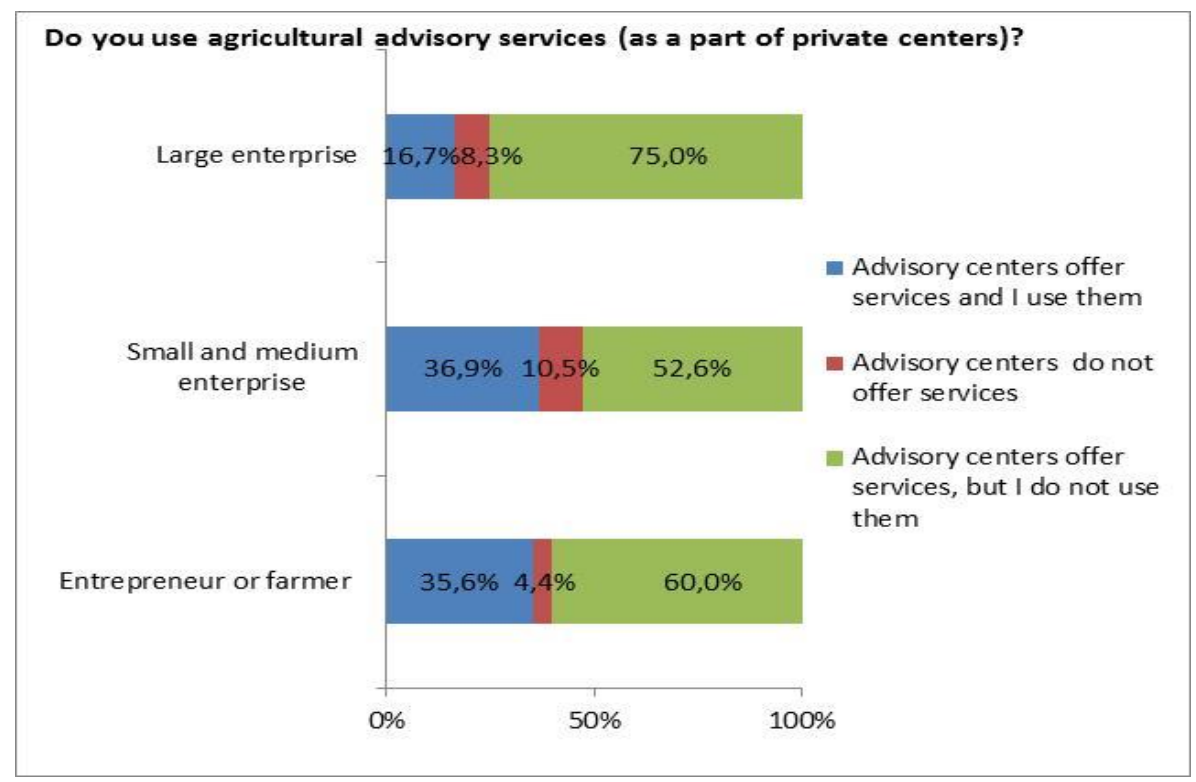

Source: Authors' research

Based on the Figure 2, as for the services of private consultant centers, results showed that enterprises are significantly more informed and aware of the presence and availability of these services, so only $4.4 \%$ of entrepreneurs and farmers, $10.5 \%$ of small and medium-sized enterprises and $8.3 \%$ of large enterprises responded that there are none. However, the level of using these services is low, hence only $35.6 \%$ of entrepreneurs and farmers, $36.9 \%$ of small and medium-sized enterprises and $16.7 \%$ of large enterprises use them. Comparing the obtained results it can be concluded that the SMEEs are not directed towards private advisory centers as providers of business advisory 
JovinS. et al.: Financial and Business Advisory Services for Small and Medium...

services, and rarely seek their help, but still more often than in the case of large enterprises.

The SMEEs sector uses these services less, due to charging fees, and these enterprises are reluctant to invest in the gaining of new knowledge and skills. For large enterprises, these services are available within the enterprise, because large enterprises, opposed to SMEEs, have their own professional staff.

Furthermore, the results showed that enterprises that use the private consulting services use them mainly for services related to access to finance, business plans, etc. (88.2\% of entrepreneurs and farmers, $93.3 \%$ of small and medium-sized enterprises, and all examined large enterprises). Services for the improvement of agricultural production are used within the national advisory services. Table 7 . shows the results of chi-square tests for the use of business advisory services in relation to the size of an enterprise.

Table 7. The results of chi-square test for testing the differences between the three groups of enterprises in the use of business advisory services in agribusiness

\begin{tabular}{|l|c|c|c|}
\hline & $\chi^{2}$ & $\mathrm{df}$ & $\mathrm{p}$ \\
\hline $\begin{array}{l}\text { Advisory services as part of national advisory } \\
\text { services }\end{array}$ & 22.80 & 4 & .000 \\
\hline $\begin{array}{l}\text { Advisory services as part of private consultant } \\
\text { centers }\end{array}$ & 5.71 & 4 & .219 \\
\hline
\end{tabular}

Source: Authors' research

Based on the Table 7, chi-square test showed that there were statistically significant differences in the use of business advisory services within the national advisory services between the observed groups of enterprises. As for the private consulting centers, differences in responses between observed groups of enterprises were not statistically significant.

Results of this research confirmed the second hypothesis $\mathrm{H} 2$ set in the introductory part of the paper: While business advisory services can significantly improve the business of small and medium-sized enterprises, entrepreneurs and farmers, they are still not used sufficiently and a certain number of small and medium-sized enterprises, entrepreneurs and farmers is unaware of their usage.

\section{Conclusions and Recommendations}

In order to establish and develop enterprises in Agribusiness, in addition to the business idea, funding is necessary. The study showed that finding 
JovinS. et al.: Financial and Business Advisory Services for Small and Medium...

appropriate funding is a greater difficulty for the SMEE sector and farmers, in comparison to large enterprises as shown by the lower average rating obtained in all the observed parameters.

Interest rates and other fees were ranked as the biggest constraint for all enterprises, but the SMEE sector and farmers rated it with the lowest average score.

By knowing that the financing of newly established, small and medium-sized enterprises and particularly entrepreneurs in agribusiness is risky, interest rates on approved loans for these enterprises become very high.

While enterprises give preference to financial services, in many cases the needs for funding occur due to inadequate management of financial resources. For this reason, an enterprise, particularly the newly established and small one, needs training and advising. Constant informing and development of professional farmers knowledge is one of the preconditions for their successful adaptation to the market. At the same time, it increases the competitiveness of an enterprise in the trade field. When the activities of an enterprise become more complex, the importance of business advisory support is increased.

Based on the data presented in the paper, it can be concluded that the SMEE sector and farmers are not sufficiently informed about the services provided by the national advisory centers. On the other hand, they are familiar with the offer of private consulting centers; however, these services are rarely used due to their market character. SMEEs that use business advisory services increasingly declare for national advisory services, and for services related to the improvement of agricultural production.

Based on research results it can be concluded that the hypotheses in the introductory parts of the paper are confirmed.

Recommendation for future research is to carry out a research of commercial banks in the Republic of Serbia and explore their views regarding issues of the financing SMEE sector in Agribusiness. That would provide more comprehensive results. Although this paper shows only one dimension of the financial constraints of the SMEEs sector from the enterprises' point of view, it is significant because the results unambiguously point to the difficult position of SMEE sector in Agribusiness. This paper can be a starting point for the improvement of their position and important not only for banks, but for the entire institutional infrastructure for the support of entrepreneurship in Agribusiness. 
JovinS. et al.: Financial and Business Advisory Services for Small and Medium...

\section{References}

Ayyagari, M., Demirguc-Kunt, A., \& Maksimovic, V. (2008). How Important Are Financing Constraints? The Role of Finance in the Business Environment. The World Bank Economic Review, 22(3), 483-516. doi:10.1093/wber/lhn018

Bygrave, W., \& Zacharakis, A. (2004). The portable MBA in Entrepreneurship. USA: John Wiley \& Sons, Inc. 3rd ed.

Cassar, G., \& Holmes, S. (2003). Capital structure and financing of SMEs: Australian evidence. Accounting and Finance, 43(2), 123-147. doi:10.1111/1467-629x.t011-00085

Cassu, B., Girardone, C., \& Molyneux, P. (2006). Introduction to banking. England: Pearson Education Limited.

Ciaian, P., Fałkowski, J., \& Kancs, (. (2010). Access to Credit, Factor Allocation and Farm Productivity: Evidence From the CEE Transition Economies, 114th Seminar of the European Association of Agricultural Economists (EAAE), Proceedings, Berlin, Germany, 1-35. (pp. 22-47). doi:10.1108/00021461211222114

Ciaian, P., Pokrivcak, J., \& Szegenyova, K. (2011). Do Agricultural Subsidies Crowdout or Stimulate Rural Credit Market Institutions?, The Case of CAP Payments: AAEA and NAREA Joint Annual Meeting, Pittsburgh, USA. 1-27, available at: http:// ageconsearch.umn.edu/bitstream/103085/2/Paper.pdf.

Janko, C., Barbara, R., Bosko, V., \& Milorad, Z. (2013). The research on people's enterprise skills in Serbia. Industrija, 41(1), 131-140. doi:10.5937/industrija413756

Filipović, S., \& Petrović, P. (2017). How to improve Entrepreneurship in the Republic of Serbia? Improving Micro and Macro Competitiveness - problems and possible solutions: Thematic collection of papers of international significance. University of Niš - Faculty of Economics. 67-85.

Hoflich, P. (2011). Banks at Risk, Global Best Practices in an Age of Turbulence. Singapore: John Wiley \& Sons.

Ljumović, I., \& Jakšić, K. (2015). Dostupnost finansijskih resursa preduzećima na severu Kosova, Zbornik Matice Srpske za društvene nauke. Novi Sad, no. 152, 3/2015, 557-569.

Maletić, R., Ćeranić, S., \& Popović, B. (2011). Mala i srednja preduzeća kao činioci smanjenja siromaštva u ruralnim zajednicama Srbije. Ekonomika poljoprivrede, Vol. 58 (1), 121-131.

Malhotra, M., Chen, Y., Criscuolo, A., Fan, Q., Hamel, I.I., \& Savchenko, Y. (2006). Expanding Access to Finance: Good Practices and Policies for Micro, Small, and Medium Enterprises. Washington, USA: World Bank. doi:10.1596/978-0-8213-7177-0

Marko, M., Sanja, F., \& Svetozar, T. (2013). Profitability of Serbian banking sector during global economic crisis. Industrija, 41(4), 39-57. doi:10.5937/industrija415096

-Ministry of Economy of Republic of Serbia, , -Ministry of Regional Development and Local Government of Republic of Serbia, , \& -National Agency for Region Development of Republic of Serbia, (2013). The report on SMEs for year 2012. Belgrade. 
JovinS. et al.: Financial and Business Advisory Services for Small and Medium...

-National Agency for Regional Development. (2013). Report on conditions, needs and problems of SMEs in Serbia in 2013.

Law on Performing Advisory and Extension Activities in Agriculture. Official Gazette of RS, (2010). 30.

Support strategy for SMEE development and competitiveness for 2015 to 2020 period. Official Gazette of $R S$, (2015). 35.

Popovic, B. (2009). Contribution of small and medium sized enterprises in development of agribusiness of Serbian Republic. Journal of Agricultural Sciences, Belgrade, 54(1), 63-80. doi:10.2298/jas0901063p

Reuvid, J. (2011). Start up \& run your own business, The essential guide to planning, funding and growing your new enterprise. UK: Kogan page. 8th ed.

Scarborough, N. (2012). Effective Small Business Management, An Entrepreneurial Approach. USA: Pearson Education Limited. 10th ed.

Stokes, D., \& Wilson, N. (2010). Small Business Management and Entrepreneurship. Hampshire, England: Cengage Learning EMEA.

-USAID. (2012). Financing the growth of small and medium enterprises, Business enabling project. Belgrade, Serbia.

van Horne, J., \& Wachowicz, J.J.R. (2007). Osnovi finansijskog menadžmenta. Beograd, Srbija: Data status.

Veselinovic, B., \& Drobnjakovic, M. (2014). Qualitative and quantitative analysis of micro and macro aspects of agricultural finance. Ekonomika poljoprivrede, 61(3), 771-787. doi:10.5937/ekopolj1403771v

Walraven, N., \& Barry, P.J. (2004). Bank risk ratings and the pricing of agricultural loans. Agricultural Finance Review, 64(2), 107-118. doi:10.1108/00214660480001157

-World Economic Forum. (2017). The Global Competitiveness Report 2016/2017. taken from http://www3.weforum.org/docs/GCR20162017/05FullReport/TheGlobalCompetitivenessReport2016-2017_FINAL.pdf (date of access 25.09.2017).

-World Bank Group. (2017). Doing Business Report. taken from http://www.doingbusiness.org/ /media/WBG/DoingBusiness/Documents/AnnualReports/English/DB17-Report.pdf (date of access 25.09.2017). 